Anna Seretny

Uniwersytet Jagielloński w Krakowie

aseretny@poczta.onet.pl

\title{
STRATEGIE UCZENIA SIĘ SŁOWNICTWA - OBCOKRAJOWCY VS. UŻYTKOWNICY JĘZYKA ODZIEDZICZONEGO
}

\section{Vocabulary Learning Strategies - Foreign Language Learners vs. Heritage Language Learners}

In an average Polish language intermediate class (level B1/B2) there are two types of learners; namely, heritage language learners (HLLs) and foreign language learners (FLLs). HLLs are of Polish origin and have gained partial knowledge of the language in a natural environment, unlike FLLs who have learnt Polish in a formal institutional setting and have no Polish roots whatsoever.

Teachers of Polish as a foreign/second language claim (in anecdotal evidence), that HLLs speak more fluently, particularly when talking about everyday topics, and that their production sounds more native like, as it is more formulaic. HLLs are, however, perceived as poorer vocabulary learners than FLLs. The aim of the research described in this article was to find out if this phenomenon can be ascribed to the different number and/or type of vocabulary learning strategies used by learners from the two groups.

Keywords: vocabulary learning strategies, Polish language learners, heritage language learners, foreign language learners

Słowa kluczowe: strategie uczenia się słownictwa, uczący się języka polskiego, użytkownicy języka odziedziczonego, obcokrajowcy 


\section{Wprowadzenie}

Specyfiką nauczania języka polskiego jako nierodzimego, zwłaszcza na poziomie samodzielności (B), jest obecność w procesie kształcenia dwu różnych grup uczących się (zob. Lipińska i Seretny, 2012b). Do pierwszej zaliczani są cudzoziemcy (foreign langugae learners) - dla nich polski jest językiem obcym poznawanym przede wszystkim w klasie, w środowisku egzo- lub endolingwalnym. Grupę drugą tworzą uczący się polskiego pochodzenia ${ }^{1}$ (heritage language learners), dla których polszczyzna wyniesiona z domu stanowi język odziedziczony (zob. Valdes, 2000; Fishman, 2001; Van Deusen-Scholl, 2003), czyli nie obcy, ale też i nie ojczysty (Lipińska i Seretny, 2012a).

Oba kręgi odbiorców, poza nieco innymi oczekiwaniami, mają także różne potrzeby, gdyż "przy podobnym ogólnym poziomie zaawansowania ich kompetencję komunikacyjną tworzą opanowane w różnym stopniu umiejętności i sprawności językowe" (Lipińska i Seretny, 2012b: 2). Dla użytkowników języka odziedziczonego (dalej: UJO) działania w obrębie kodu mówionego (interakcyjne, produkcyjne oraz mediacyjne) są zdecydowanie mniej problematyczne niż te, które wymagają posługiwania się kodem pisanym - bywa bowiem, że niektórzy z nich znają go bardzo słabo. Obcokrajowcy natomiast (dalej: O) legitymują się zazwyczaj bardziej wyrównanym poziomem umiejętności językowych, choć zdecydowanie częściej obserwuje się u nich deficyt sprawności słuchowo-ustnych przy nieznacznie lepiej opanowanych manualnowzrokowych. Różnice między UJO a O są rezultatem zarówno luk pojawiających się u nich w odmiennych obszarach kompetencji lingwistycznych, jak i innego poziomu automatyzacji opanowanych już struktur. Spore rozbieżności między eksplicytną wiedzą językową cudzoziemców (O) a umiejętnościami proceduralnymi sprawiają, że ich produkcję cechuje brak płynności. Wskutek niepełnej znajomości środków językowych często też popełniają błędy, a głoski i ich kombinacje artykułują przeważnie z wyraźnym, obcym akcentem. Działania komunikacyjne UJO, nieposiadających z reguły żadnej (lub prawie żadnej) eksplicytnej wiedzy językowej ${ }^{2}$, są natomiast sprawne i na ogół fortunne. Zasób znanych im środków językowych rzadko wykracza jednak poza tzw. minimum. Produkcja UJO, choć płynna, daleka jest również od poprawności wskutek

\footnotetext{
${ }^{1}$ Najczęściej są to przedstawiciele drugiego lub trzeciego pokolenia emigracyjnego.

2 Jest to zjawisko charakterystyczne dla procesu przyswajania języka, tj. nabywania umiejętności komunikacyjnych w toku naturalnych interakcji z innymi użytkownikami. Przyswajanie pozostaje więc w opozycji do uczenia się, tj. świadomego nabywania doświadczeń, wyrażającego się modyfikacją zachowań językowych (zob. Krashen, 1982), choć oba procesy mogą się na siebie nakładać.
} 
niedorozwoju/niepełnego rozwoju kompetencji gramatyczno-leksykalnej, będącego wynikiem przełączania się przez nich na język kraju osiedlenia/ szkolnej edukacji (zob. Polinsky i Kagan, 2007). Ich wymowa także często odbiega od natywnej.

Priorytety dydaktyczne w przypadku UJO i O są więc odmienne, nie przeszkadza to jednak w tworzeniu tzw. grup mieszanych, tj. składających się z przedstawicieli obu kręgu odbiorców.

\section{Kompetencja leksykalna cudzoziemców i użytkowników języka odziedziczonego}

Płaszczyzna leksykalna jest tym obszarem, na którym różnice między UJO a O zaznaczają się z pełną wyrazistością.

UJO sprawnie posługują się słowami w aktach komunikacji, a $w$ razie braków potrafią stosować proste omówienia i/lub parafrazy ${ }^{3}$, co sprawia wrażenie, że ich kompetencja leksykalna jest prawidłowo ukształtowana. Słownictwo, którym się posługują jest jednakże ubogie, często ograniczone do "do-

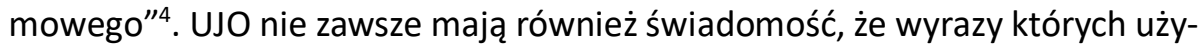
wają, w niektórych kontekstach są co najmniej niestosowne ${ }^{5}$. Cechuje ich także niewielka "ciekawość leksykalna" - zazwyczaj żywią bowiem przekonanie, że rozumieją w zasadzie wszystko.

Zakres słownictwa znanego $O$ wydaje się natomiast znacznie skromniejszy (zob. Seretny, 2011). Często bywa też wyraźnie wyznaczony przez ramy podręcznika, z którego się dotychczas uczyli. W przeciwieństwie do swoich kolegów polskiego pochodzenia, znanymi sobie wyrazami posługują się mniej płynnie - mechanizm przywołania umożliwiający dostęp do zasobów zgromadzonych w słowniku umysłowym działa bowiem w ich przypadku zdecydowanie mniej sprawnie. Słabiej znają również leksykę potoczną. Zdecydowanie częściej natomiast niż UJO są świadomi "wagi" słów, wynikającej z ich przynależności do określonej odmiany/określonego rejestru języka, wyraźniej także odczuwają ich brak.

\footnotetext{
${ }^{3}$ Innymi słowy, luki leksykalne nie stają się przyczyną blokady komunikacji.

${ }^{4}$ Wielkość zasobu leksykalnego UJO może być bardzo zróżnicowana (zob. Seretny 2011). Determinują go przede wszystkim: (1) stopień zanurzenia w języku w środowisku domowym (polszczyzną mogą władać oboje z rodziców lub tylko jedno z nich); (2) dbałość rodzica/rodziców dziecka o kontakt z językiem, tj. czytanie książek, wspólne rozmowy na temat wydarzeń, książek filmów, uczestnictwo w wydarzeniach kulturalnych, troska o poprawne używanie języka (zob. Lipińska i Seretny, 2012a).

${ }^{5} \mathrm{~Np}$. nazywanie toalety kiblem w prośbie kierowanej do nauczyciela: Czy mogę iść do kibla?
} 
Działania dydaktyczne mające na celu poszerzanie kompetencji leksykalnej zazwyczaj przynoszą lepsze wyniki w przypadku O niż UJO ${ }^{6}$. Uczący się polskiego pochodzenia dość opornie włączają do aktywnego słownika nowe wyrazy, nie zawsze widzą bowiem konieczność pracy nad leksyką. Powody po temu są co najmniej dwa: po pierwsze, nieznajomość słów rzadko w ich przypadku staje się przyczyną bariery komunikacyjnej, gdyż z lukami radzą sobie nieźle, z powodzeniem stosując rozmaite strategie kompensacyjne; po drugie zaś, nie mają nawyku uczenia się polskich słów, ponieważ do tej pory przyswajali je bez udziału świadomości, implicytnie, w toku domowych interakcji. Obcokrajowcy natomiast rozumieją potrzebę poznawania/uczenia się nowych wyrazów, czują bowiem, że braki leksykalne ograniczają ich możliwości komunikacyjne. Starają się więc systematycznie pracować nad słownictwem, co stopniowo przekłada się na coraz wyższą jakość tworzonych przez nich wypowiedzi ustnych i pisemnych. Wydaje się więc, że O w mniejszym stopniu niż UJO dotyka zjawisko określane mianem leksykalnego plateau (Julian 2000).

\section{Cel badań}

W niniejszym artykule przedstawione zostaną wyniki badań, które miały na celu ustalenie, czy pierwotny sposób poznawania języka, naturalny w przypadku UJO vs. szkolny w przypadku O (zob. Lipińska, 2003), wpływa na liczbę oraz rodzaj strategii uczenia się słownictwa stosowanych przez przedstawicieli obu grup. Uczący się, którzy są bardziej wszechstronni w podejmowanych przez siebie działaniach, osiągają bowiem lepsze wyniki w nauce języka, w tym w opanowywaniu leksyki.

Jeśliby więc słabsze rezultaty UJO można było przypisać, po części przynajmniej, stosowaniu przez nich mniejszej liczby/mniej urozmaiconych sposobów uczenia się słów, koniecznością stałaby się modyfikacja dotychczasowego modelu kształcenia, w którym nie różnicuje się technik rozwijania kompetencji leksykalnej w pracy z przedstawicielami obu grup ${ }^{7}$.

Postawiona hipoteza badawcza brzmiała więc:

\footnotetext{
${ }^{6}$ Na podstawie niezweryfikowanych danych, jakimi są: obserwacje i odczucia nauczycieli prowadzących zajęcia w grupach mieszanych, czyli UJO + O w Centrum Języka i Kultury Polskiej w Świecie UJ, poddane analizie wyniki testów osiągnięć uczących się z obu grup oraz wyniki ich egzaminów ustnych.

${ }^{7}$ Modyfikacja ta mogłaby polegać, na przykład, na zwiększeniu nacisku na eksplicytne nauczanie leksyki w przypadku UJO (zob. m.in. Komorowska, 1988; Chodkiewicz, 2000; Schmitt, 2000; Nation, 2001; Seretny, 2015), a także wprowadzenie do nauczana treningu w zakresie stosowania określonych strategii.
} 
Strategie uczenia się słownictwa - obcokrajowcy vs. użytkownicy języka...

słabsza dynamika przyrostu zasobu leksykalnego u UJO w porównaniu z tq, jakq obserwuje się u uczq̨cych się polszczyzny $O$, jest wynikiem stosowania przez UJO mniejszej liczby strategii/mniej zróżnicowanych strategii uczenia się słownictwa.

\section{Narzędzie badawcze}

Tematyka strategii uczenia się słownictwa w języku obcym (dalej: SUS) stała się odrębnym obszarem badawczym dopiero pod koniec lat dziewięćdziesiątych $^{8}$. Wcześniej zagadnienia związane ze sposobami, jakie uczący się wykorzystują, opanowując leksykę, włączane były w ogólny nurt badań strategii uczenia się zapoczątkowany przez takich glottodydaktyków jak Rubin (1975), Oxford (1990), czy O'Malley i Chamot (1990).

Pierwszą pełniejszą taksonomię SUS przedstawił w 1997 roku Schmitt. Zasadniczo opiera się ona na koncepcji Oxford (1990), wprowadzone jednak do niej zostały modyfikacje wynikające ze specyfiki opanowywanego materiału językowego, jakim jest leksyka. Schmitt zwrócił na przykład uwagę na konieczność podziału działań podejmowanych przez uczących się nie tylko w zależności od rodzaju tych działań (kryterium A), lecz także od fazy obcowania z nowym wyrazem (kryterium B). Najpierw bowiem muszą ustalić, co dane słowo znaczy (faza I), następnie spróbować je zapamiętać (faza II) i dopiero wówczas zastosować taktyki umożliwiające opanowanie umiejętności aktywnego posługiwania się nim w aktach komunikacji (faza III).

Działania, jakie uczący się podejmują, by odkryć znaczenie nieznanego im słowa, zależne są nie tylko od poziomu ich umiejętności językowych, lecz także od posiadanych kompetencji ogólnych (zob. ESOKJ 2003: 21-23). Niektórzy aktywizują w tym celu całą swoją wiedzę językową i pozajęzykową, inni analizują wskazówki kontekstowe, jeszcze inni sięgają do materiałów pomocniczych lub proszą o pomoc nauczyciela, kolegę czy rodzimego użytkownika. Dlatego też strategie pozwalające na ustalenie znaczenia, określone jako poznawcze, angielski badacz podzielił na samodzielne, mające charakter indywidualny oraz społeczne, tj. oparte na interakcji.

Stykając się z nowymi strukturami leksykalnymi, uczący się próbują wbudować je w obręb własnej struktury poznawczej tak, by móc z nich swobodnie/sprawnie korzystać w aktach komunikacji. Podejmowane przez nich działania wspomagające zapamiętywanie mają charakter pamięciowy lub/i kognitywny. Niektórzy łączą więc "nieznane" ze "znanym", kierując się podobieństwem, analogią, kontrastem itp. Inni stosują techniki mnemoniczne, próbują

\footnotetext{
8 Jeszcze w pierwszej połowie lat dziewięćdziesiątych temat ten bardzo rzadko pojawiał się na konferencjach poświęconych nauczaniu angielskiego (Schmitt, 2000: 107).
} 
układać zdania z nowymi słowami, grupują je tematycznie lub analizują ich wymowę, pisownię itp. Są też i tacy, którzy przygotowanymi fiszkami (ang. flash cards) wyklejają mieszkanie.

Bardziej świadomi uczący się starają się monitorować proces opanowywania słownictwa. Chcą mieć bowiem pewność, że cechuje go odpowiednia dynamika. Gdy zauważają, że przyrost zasobu leksykalnego jest niewielki, podejmują różnorodne działania naprawcze.

W badaniach strategii stosowanych przez poznających polszczyznę UJO i O w celu lepszego opanowania słownictwa wykorzystany został zmodyfikowany kwestionariusz Schmitta ${ }^{9}$ (dostosowany do potrzeb polszczyzny), w którym wydzielono, zgodnie z koncepcją autora, trzy grupy strategii: (i) ułatwiające ustalenie znaczenia, (ii) wspomagające zapamiętywanie oraz (iii) pozwalające na monitoring postępów w nauce (zob. Tabela 1).

\begin{tabular}{|l|c|c|}
\hline \multicolumn{2}{|c|}{ STRATEGIE } \\
\hline $\begin{array}{l}\text { UŁATWIAJACE USTALENIE ZNACZENIA } \\
\text { Gdy nie wiem, co dane słowo znaczy, to ... }\end{array}$ & indywidualne & społeczne \\
\hline $\begin{array}{l}\text { WSPOMAGAJACE ZAPAMIĘTYWANIE } \\
\text { Gdy chcę zapamiętać znaczenie słowa, to ... }\end{array}$ & pamięciowe & kognitywne \\
\hline $\begin{array}{l}\text { POZWALAJACE NA MONITORING POSTĘPÓW } \\
\text { Gdy chcę sprawdzić, czy znam coraz więcej słów, to ... }\end{array}$ & \multicolumn{2}{|c|}{ metakognitywne } \\
\hline
\end{tabular}

Tabela 1: Podział SUS (na podst. Schmitt, 1997).

Zamieszczona po metryczce instrukcja brzmiała:

Proszę uważnie przeczytać poniższe stwierdzenia, a następnie zaznaczyć, w jakim stopniu odnosza się one do Pana/i. Proszę zaznaczać takie strategie, które Pan/i rzeczywiście stosuje, a nie te, które wydaja się Panu/Pani sensowne.

Pod nią zaś znalazła się bateria stwierdzeń typu:

Gdy nie wiem, co dane słowo znaczy to:

1. analizuję jego budowę (temat, prefiksy itp.), szukając znajomych części

2. staram się ustalić, jaka to część mowy (rzeczownik, przymiotnik ...)

3. zastanawiam się, czy nie ma w moim języku słowa, które brzmi podobnie

Uczący się mieli przypisać wymienionym działaniom odpowiednią wartość, posługując się pięciostopniową skalą Likerta:

- nigdy tak nie robię 1

- raczej tak nie robię 2

- czasem tak robię 3

${ }_{9}^{9}$ Po merytorycznej analizie i adaptacji narzędzia badawczego przeprowadzony został jego pilotaż, w wyniku którego wprowadzono stosowne zmiany. 
Strategie uczenia się słownictwa - obcokrajowcy vs. użytkownicy języka...

- $\quad$ często tak robię

4

- $\quad$ zawsze tak robię

5

\section{Organizacja badań i ich uczestnicy}

Badanie zostało przeprowadzone w 2014 roku wśród uczestników letnich kursów organizowanych przez Szkołę Języka i Kultury Polskiej Uniwersytetu Jagiellońskiego ${ }^{10}$. Wzięły w nim udział 82 osoby uczące się polszczyzny na poziomie samodzielności językowej (B1.2/B2.1/B2.1/B2.2). Na tym etapie kształcenia spotyka się bowiem najwięcej UJO (zob. Lipińska i Seretny, 2012b), na nim również powinien dokonywać się duży jakościowy i ilościowy przyrost zasobu leksykalnego uczących się ze względu na rosnący stopień trudności działań językowych, jakich się od nich oczekuje (zob. ESOKJ 2003).

Badanie miało charakter anonimowy. Respondenci, wypełniając metryczkę, określali jedynie swój wiek, płeć, narodowość oraz język pierwszy. Zaznaczali także, czy znają polski z domu, czy też poznawali go wyłącznie systemem szkolnym. Dodatkowo, mieli również wskazać powody, dla których uczą się polszczyzny, tj. źródła motywacji opanowywania języka rzadziej używanego, mniej popularnego.

Spośród 82 osób, które wypełniły ankietę, 42 określiły się jako cudzoziemcy, pozostałe (40) zaznaczyły, iż częściową znajomość polszczyzny wyniosły z domu. Większość badanych w obu podgrupach stanowiły kobiety (zob. Tabela 2), poniżej 30 roku życia (zob. Tabela 3).

\begin{tabular}{|l|c|c|c|}
\hline \multicolumn{4}{|c|}{ LICZEBNOŚĆ } \\
\hline & KOBIETY & MĘŻCZYŹNI & KOBIETY /MĘŻCZYŹNI \\
\hline Obcokrajowcy (0) & 34 & 8 & 42 \\
\hline Uczący się polskiego pochodzenia (UJO) & 29 & 11 & 40 \\
\hline Razem & 63 & 19 & 82 \\
\hline
\end{tabular}

Tabela 2: Płeć badanych z uwzględnieniem sposobu poznawania języka (opracowanie własne).

\begin{tabular}{|l|c|c|}
\hline \multicolumn{2}{|c|}{ WIEK } \\
\hline & $16-20$ & $21-30$ \\
\hline Obcokrajowcy (O) & 34 & 8 \\
\hline Uczący się polskiego pochdzenia (UJO) & 29 & 11 \\
\hline
\end{tabular}

Tabela 3: Wiek badanych z uwzględnieniem sposobu poznawania języka (opracowanie własne).

\footnotetext{
${ }^{10}$ Miało ono charakter wstępny. Planowane są bowiem szerokie badania kompetencji językowych i strategii uczenia się rodzimych użytkowników polszczyzny, uczących się jej cudzoziemców oraz osób mieszkających za granicą, które częściową znajomość polszczyzny wyniosły z domu.
} 
Motywacja, dla której respondenci z obu grup podjęli naukę polszczyzny, okazała się, zgodnie z przewidywaniami, zdecydowanie różna. Wśród UJO przeważały względy rodzinne oraz, w niewielkim stopniu, nauka dla przyjemności, która dla O okazała się najważniejsza. W następnej kolejności wymienione zaś zostały przez nich powody edukacyjne/zawodowe (zob. Tabela 4).

\begin{tabular}{|l|c|c|}
\hline & $\begin{array}{c}|c| \\
\text { ŹRÓDŁA MOTYWACII } \\
(\mathbf{O})\end{array}$ & $\begin{array}{c}\text { UCZĄCY SIĘ POLSKIEGO POCHODZENIA } \\
\text { (UJO) }\end{array}$ \\
\hline powody zawodowe /edukacyjne & 11 & 5 \\
\hline nauka dla przyjemności & 25 & 7 \\
\hline względy rodzinne & 4 & 28 \\
\hline inne & 2 & - \\
\hline
\end{tabular}

Tabela 4: Motywacja respondentów z uwzględnieniem sposobu poznawania języka (opracowanie własne).

\begin{tabular}{|l|c|c|l|c|c|}
\hline \multicolumn{7}{|c|}{ NARODOWOŚCI } \\
\hline \multicolumn{2}{|c|}{ KRAJ } & LBCOKRAJ OWCY (O) & $\%$ & \multicolumn{1}{c|}{ KRAZCY SIE POLSKIEGO POCHODZENIA (UJO) } \\
\hline Ukraina & 7 & 16,6 & USA & 24 & 60 \\
Stowacja & 6 & 14,3 & Ukraina & 4 & 10 \\
Białoruś & 3 & 7,1 & Niemcy & 3 & 7,5 \\
Rosja & 3 & 7,1 & Kanada & 3 & 7,5 \\
Chiny & 2 & 4,8 & Wielka Brytania & 2 & 5 \\
Czechy & 2 & 4,8 & Białoruś & 1 & 2,5 \\
Hiszpania & 2 & 4,8 & Holandia & 1 & 2,5 \\
Niemcy & 2 & 4,8 & Finlandia & 1 & 2,5 \\
Rumunia & 2 & 4,8 & Włochy & 1 & 2,5 \\
USA & 2 & 4,8 & & & \\
Wielka Brytania & 2 & 4,8 & & & \\
Australia & 1 & 2,4 & & & \\
Chorwacja & 1 & 2,4 & & & \\
Estonia & 1 & 2,4 & & & \\
Francja & 1 & 2,4 & & & \\
Holandia & 1 & 2,4 & & & \\
totwa & 1 & 2,4 & & & \\
Mołdawia & 1 & 2,4 & & & \\
Portugalia & 1 & 2,4 & & & \\
Węgry & 1 & 2,4 & & & \\
\hline
\end{tabular}

Tabela 5: Narodowość respondentów z uwzględnieniem sposobu poznawania języka (opracowanie własne).

Uczestnicy badań pochodzili z 23 krajów świata ${ }^{11}$ (zob. Tabela 5). Wśród UJO dominowali Amerykanie o polskich korzeniach (60\%), wśród O przeważali zaś nasi wschodni sąsiedzi (łącznie ok. 41\%).

11 Duże zróżnicowanie narodowościowe uczących się polszczyzny jest charakterystyczne dla procesu kształcenia zachodzącego w środowisku endolingwalnym. 


\section{Wyniki badań}

Uzyskane wyniki pozwalają stwierdzić, że obie grupy, wbrew przewidywaniom, dość podobnie wykorzystują strategie uczenia się słownictwa (zob. tabela 6). Dotyczy to zarówno tych ułatwiających ustalenie znaczenia (UJO/64,82 vs. O/66,54 przy maksymalnym do siągnięcia wyniku 110), jak i wspomagających zapamiętywanie (UJO/106,15 vs. O/111,33 przy maksymalnym do osiągnięcia wyniku 200) oraz umożliwiających monitoring postępów w nauce (UJO/14,65 vs. O/16,00 przy maksymalnym do osiągnięcia wyniku 30). Warto przy tym zauważyć, iż średnie wyniki obu grup nie są wysokie (zob. Tabela 6).

\begin{tabular}{|l|c|c|c|c|c|c|c|}
\hline UCZĄCY SIE & LICZBA & \multicolumn{2}{|c|}{$\begin{array}{r}\text { STRATEGIE } \\
\text { UtATWIAJACE } \\
\text { USTALENIE } \\
\text { ZNACZENIA }\end{array}$} & \multicolumn{2}{|c|}{$\begin{array}{r}\text { STRATEGIE } \\
\text { WSPOMAGAJACE } \\
\text { ZAPAMIĘTYWANIE }\end{array}$} & $\begin{array}{r}\text { STRATEGIE } \\
\text { POZWALAJACE NA } \\
\text { MONITORING } \\
\text { POSTĘPÓW }\end{array}$ \\
\hline & 42 & 66,54 & 9,19 & 111,33 & 22,78 & 16,00 & 3,19 \\
\hline O & 40 & 64,82 & 12,36 & 106,15 & 22,62 & 14,65 & 4,02 \\
\hline UJO & średnia & odch. stand. & średnia & odch. stand. & średnia & odch. stand. \\
\hline
\end{tabular}

Tabela 6: Wyniki badań strategii uczenia się słownictwa UJO i O (opracowanie własne).

Wartość odchylenia standardowego we wszystkich przypadkach wskazuje na pewną dyspersję wyników, która nie okazała się jednak świadectwem zasadniczego zróżnicowania badanych grup. Przeprowadzony test t-Studenta dla grup równolicznych o równych wariancjach (przy stopniu prawdopodobieństwa $\alpha=0,05$, stopniu swobody $d f=80$ i przedziale ufności $p<0,01$ ) wykazał bowiem jednoznacznie, że różnice między średnimi wynikami UJO i O w żadnym przypadku nie są statystycznie istotne, gdyż wartość t nigdy nie przekraczała 1,96 (zob. Tabela 7).

\begin{tabular}{|l|l|}
\hline \multicolumn{1}{|c|}{ STRATEGIE } & \multicolumn{1}{|c|}{ WYNIKU TESTU T-STUDENTA } \\
\hline UŁATWIAJĄCE USTALENIE ZNACZENIA & $\mathrm{t}=0,71<1,96$ \\
& $\begin{array}{l}\mathrm{df}=80(\alpha=0,05) \\
\mathrm{p}<0,01\end{array}$ \\
\hline WSPOMAGAJĄCE ZAPAMIĘTYWANIE & $\mathrm{t}=1,03<1,96$ \\
& $\mathrm{df}=80(\alpha=0,05)$ \\
& $\mathrm{p}<0,01$ \\
\hline POZWALAJĄCE NA MONITORING POSTĘPÓW & $\mathrm{t}=1,69<1,96$ \\
& $\mathrm{df}=80(\alpha=0,05)$ \\
& $\mathrm{p}<0,01$ \\
\hline
\end{tabular}

Tabela 7: Wyniki testu t-Studenta (opracowanie własne).

Statystycznie istotną różnicę zaobserwowano jedynie w przypadku stosowania pojedynczych strategii (zob. Tabela 8). UJO, na przykład, próbując 
ustalić znaczenie, bardzo rzadko zastanawiają się nad tym, jaką częścią mowy jest dany wyraz (indywidualna strategia ułatwiająca zapamiętanie znaczenia). Obcokrajowcy natomiast informację tą uznają za ważną, dzięki niej mogą bowiem odwołać się do określonego paradygmatu odmiany (przejaw tzw. myślenia gramatycznego poprzedzającego semantyczne). UJO zdają się w tym przypadku bardziej polegać na intuicji. Często nie mają także odpowiedniej wiedzy metajęzykowej, by strategię taką zastosować, część z nich nie wie bowiem, że poduszka to rzeczownik, choć potrafi stosować odpowiednie do kontekstu formy morfologiczne tego wyrazu. Różnica zaznacza się także w przypadku strategii społecznych stosowanych w celu ustalenia znaczenia. Dla UJO źródłem wiedzy leksykalnej są członkowie rodziny (najczęściej są to zapewne rodzice lub dziadkowie, rzadziej rodzeństwo ${ }^{12}$ ), dla $\mathrm{O}$, ze zrozumiałych względów, są to koledzy.

\begin{tabular}{|l|l|c|c|}
\hline \multicolumn{1}{|c|}{ TYP STRATEGII } & \multicolumn{1}{|c|}{ DZIAtANIA } & O & UJO \\
\hline STRATEGIE & $\begin{array}{l}\text { staram się ustalić, jak to część mowy (strategia indywidualna) } \\
\text { UtATWIAJACE }\end{array}$ & $\mathrm{V}$ & \\
USTALENIE ZNACZENIA & $\begin{array}{l}\text { pytam o znaczenie kolegę (strategia społeczna) } \\
\text { pytam o znaczenie członka rodziny (strategia społeczna) }\end{array}$ & $\mathrm{V}$ & \\
\hline $\begin{array}{l}\text { STRATEGIE WSPOMAGA- } \\
\text { JAZCE ZAPAMIĘTYWANIE }\end{array}$ & $\begin{array}{l}\text { zapamiętuję, jak dane słowo się odmienia (strategia pamięciowa) } \\
\text { - uczę się słów ze słowniczka w podręczniku (strategia kognitywna) }\end{array}$ & $\mathrm{v}$ & $\mathrm{V}$ \\
\hline $\begin{array}{l}\text { STRATEGIE POZWALAJĄCE } \\
\text { NA MONITORING } \\
\text { POSTĘPÓW }\end{array}$ & $\begin{array}{l}\text { regularnie powtarzam słowa w parach - wyraz polski + wyraz w moim } \\
\text { języku (strategia metakognitywna) }\end{array}$ & $\mathrm{v}$ & \\
\hline
\end{tabular}

Tabela 8: Wyniki testu t-Studenta dla poszczególnych strategii - wartość statystycznie istotna t > 1,96 (źródło: opracowanie własne).

W przypadku strategii wspomagających zapamiętywanie dwie zasadniczo różnicowały badane grupy. UJO zdecydowanie częściej niż O starają się zapamiętać, jak dany wyraz się odmienia, rzadziej natomiast uczą się słówek z podręcznika. Podobnie jest w przypadku strategii metakognitywnej polegającej na powtarzaniu wyrazów w parach J1-J2. Zdecydowanie częściej stosują ją uczący się języka obcokrajowcy niż częściowo dwujęzyczni użytkownicy języka odziedziczonego.

Różnice zaobserwowane w przypadku poszczególnych strategii, jak już wspomniano, nie miały jednakże wpływu na ogólne wyniki obu grup.

Ciekawe natomiast wygląda wybór strategii najczęściej stosowanych przez uczących się obu grup, tj. uważanych za skuteczne (zob. Tabela 9) oraz tych, które postrzegane są jako mniej efektywne i w konsekwencji rzadziej przez nich używane (zob. Tabela 10).

Najpopularniejszym sposobem pozwalającym ustalić znaczenie nieznanej jednostki leksykalnej okazała się, zarówno w przypadku UJO, jak i O, analiza wskazówek kontekstowych. Skutecznym sposobem odkrycia znaczenia dla

${ }^{12}$ Część UJO z rodzeństwem, gdy nie ma rodziców, porozumiewa się w języku kraju osiedlenia. 
Strategie uczenia się słownictwa - obcokrajowcy vs. użytkownicy języka...

UJO okazała się również analiza "znajomych części" wyrazu, dla O zaś sprawdzenie znaczenia w słowniku. Jako najbardziej efektywne działania interakcyjne prowadzące do odkrycia znaczenia słowa uczący się obu grup zgodnie wskazali prośbę o wyjaśnienie skierowaną do nauczyciela.

Spośród strategii wspomagających zapamiętywanie największą popularnością u obu grup cieszyły się: zapamiętywanie pisowni wyrazów oraz notowanie tych, które pojawiają się na lekcji. Obcokrajowcy dużo częściej decydują się na ćwiczenie wymowy nowego słowa, by je zapamiętać, O natomiast próbują wykorzystać w tym celu własne doświadczenia językowe/sytuacyjne.

Monitorowanie postępów w nauce w przypadku UJO najczęściej polega na kontakcie z tekstami mówionymi i pisanymi, O starają się zaś jak najwięcej nowo poznanych wyrazów używać w aktach komunikacji.

\begin{tabular}{|c|c|c|c|}
\hline TYP STRATEGII & DZIAŁANIA & UJO & $\mathrm{O}$ \\
\hline STRATEGIE & - analizuję kontekst, by odgadnąć znaczenie słowa & $\sqrt{ }$ & $\sqrt{ }$ \\
\hline UŁATWIAJĄCE & • proszę nauczyciela o wyjaśnienie znaczenia & $\sqrt{ }$ & v \\
\hline USTALENIE & - sprawdzam znaczenie w słowniku dwujęzycznym & & $\sqrt{ }$ \\
\hline ZNACZENIA & - analizuję budowę słowa (temat, prefiksy ...), szukając znajomych części & $\mathrm{V}$ & \\
\hline STRATEGIE & • staram się zapamiętać, jak dane słowo się pisze & $\mathrm{V}$ & $\mathrm{V}$ \\
\hline WSPOMAGAJĄCE & • notuję wyrazy, które pojawiają się na lekcji & $\sqrt{ }$ & $\sqrt{ }$ \\
\hline \multirow[t]{2}{*}{ ZAPAMIĘTYWANIE } & • staram się zapamiętać, jak dane słowo się wymawia & & $\checkmark$ \\
\hline & • łączę znaczenie słowa z własnym doświadczeniem & $\mathrm{V}$ & \\
\hline STRATEGIE & - staram się używać jak najwięcej nowo poznanych słów w mówieniu i pisaniu & & $\mathrm{V}$ \\
\hline POZWALAJĄCE NA & • dużo czytam i słucham w języku polskim & 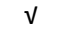 & \\
\hline MONITORING & & & \\
\hline POSTĘPÓW & & & \\
\hline
\end{tabular}

Tabela 9: Strategie uczenia się słownictwa najchętniej stosowane przez UJO i O (opracowanie własne)

\begin{tabular}{|c|c|c|c|}
\hline TYP STRATEGII & DZIAtANIA & UJO & 0 \\
\hline STRATEGIE & - nie zastanawiam się nad znaczeniem danego słowa, chyba, że pyta o nie nauczyciel & $\mathrm{V}$ & $\mathrm{V}$ \\
\hline UŁATWIAJĄCE & • proszę nauczyciela o przetłumaczenie słowa na mój język & $\mathrm{v}$ & $\mathrm{v}$ \\
\hline USTALENIE & - sprawdzam znaczenie słowa w słowniku jednojęzycznym & $\mathrm{v}$ & \\
\hline ZNACZENIA & - ustalam znaczenie słowa w trakcie pracy w grupie & & $\checkmark$ \\
\hline STRATEGIE & • podkreślam pierwszą literę słowa & $\mathrm{V}$ & $\mathrm{V}$ \\
\hline WSPOMAGAJĄCE & - robię flash cards & $\mathrm{v}$ & $\mathrm{v}$ \\
\hline \multirow[t]{2}{*}{ ZAPAMIĘTYWANIE } & - robię swoje listy wyrazów & & $v$ \\
\hline & • uczę się stów z podręcznika & $\mathrm{v}$ & \\
\hline STRATEGIE & - robię sobie regularnie testy słownikowe & $\sqrt{ }$ & $\sqrt{ }$ \\
\hline POZWALAJĄCE NA & & & \\
\hline MONITORING & & & \\
\hline POSTĘPÓW & & & \\
\hline
\end{tabular}

Tabela 10: Strategie uczenia się słownictwa najrzadziej stosowane przez UJO i O (opracowanie własne).

Dla przedstawicieli obu grup najmniej pożądanym działaniem było ignorowanie nieznanych wyrazów, za nieefektywny sposób uznali także prośbę o jego 
przetłumaczenie na język pierwszy. UJO bardzo niechętnie sięgają po słownik jednojęzyczny, by ustalić znaczenie słowa, O natomiast nie wierzą w skuteczność działań grupowych. Zapamiętywania, zdaniem UJO i O, nie wspomaga ani podkreślanie pierwszej litery nowego słowa, ani robienie fiszek (flash cards). Obcokrajowcy nie widzą także sensu w przygotowywaniu własnych list, UJO z kolei za nieefektywne uważają uczenie się słów z podręcznika (sic!). Obie grupy zgodnie stronią zaś od robienia sobie testów słownikowych.

\section{Podsumowanie}

Prowadzone badania miały ustalić, czy słabszą dynamikę przyrostu zasobu leksykalnego obserwowanego u użytkowników języka odziedziczonego w porównaniu z tą, jaką odnotowuje się uczących się polszczyzny obcokrajowców ${ }^{13}$, można przypisać mniej intensywnemu stosowaniu przez UJO strategii uczenia się słownictwa. Uzyskane w ich trakcie wyniki pokazały, że czynnik ten nie ma tak istotnego znaczenia, jakie mu w założeniach przypisywano - różnice wyników obu grup nie okazały się bowiem statystycznie istotne. Innymi słowy, średni wskaźnik liczby i użycia SUS u cudzoziemców nie okazał się znacząco wyższy niż u uczących sie o polskich korzeniach.

W badaniach ilościowych żadna z odpowiedzi respondentów nie podlegała jednak weryfikacji. Nie do końca wiadomo zatem, czy rzeczywiście działają oni w taki sposób, w jaki deklarują i czy czynią to z deklarowaną częstością. Wątpliwości tego rodzaju pojawiły się w trakcie analiz poszczególnych odpowiedzi. Zaskakujące było, na przykład, stwierdzenie UJO, iż monitorują oni swoje postępy w nauce słownictwa dużo czytając i słuchając, przeczy to bowiem rzeczywistości dydaktycznej. UJO są zazwyczaj mało wprawnymi czytelnikami, często stroniącymi od jakiejkolwiek lektury. Można także przypuszczać, iż odnosili się oni raczej do słyszenia języka (proces fizyczny, naturalny w sytuacji zanurzenia) niż słuchania tekstów (proces mentalny, podejmowany świadomie). Nie mniej dziwne było także stwierdzenie respondentów obu grup, iż tłumaczenie na język pierwszy uważają za mało efektywną strategię poznawania znaczenia, gdy $\mathrm{O} w$ tym samym badaniu stwierdzili, iż uczą się wyrazów w parach J1-J2, a w zeszytach i UJO, i O w dalszym ciągu najczęściej pojawiają się "dwujęzyczne słupki" wyrazów (obserwacja dydaktyczna).

Niezależnie od wspomnianych sprzeczności, uzyskanych wyników i tak nie można byłoby uznać za wiążące: badanie miało charakter pilotażowy,

\footnotetext{
${ }^{13} \mathrm{Na}$ podstawie niezweryfikowanych danych naukowych (anegdotal evidence), tj. obserwacji procesu kształcenia, wyników testów osiągnięć, prac bieżących oddawanych przez uczących się.
} 
Strategie uczenia się słownictwa - obcokrajowcy vs. użytkownicy języka...

grupa respondentów była bowiem nieliczna i mało reprezentatywna ${ }^{14}$, co w analizach ilościowych ma znaczenie kluczowe. Konieczne wydaje się zatem przeprowadzenie badań SUS na szerszą skalę, w których jednakże, w celu podniesienia rzetelności otrzymywanych rezultatów, komponent ilościowy zostanie uzupełniony jakościowym, opartym na przykład, na protokole głośnego myślenia (zob. Pawlak, 2009). Jego włączenie pozwoli nie tylko weryfikować odpowiedzi-deklaracje udzielane przez uczących się, lecz również ustalić, co, tj. jakie czynniki w konkretnych przypadkach decydują o zastosowaniu określonych strategii, a także czy rodzaj podejmowanych działań jest odpowiednio dostosowany do wykonywanych zadań.

\section{BIBLIOGRAFIA}

Chodkiewicz, H. 2000. Vocabulary Acquisition form the Written Context. Lublin: Wydawnictwo UMCS.

Europejski System Opisu Kształcenia Językowego: Nauczanie, Uczenie się, Ocenianie. 2003. Warszawa: CODN.

Fishman, J. 2001. "300-plus years of heritage language education in the United States". (w) Heritage Languages in America: Preserving a National Resource. (red. Peyton, J.K.; Ranard, D.A. i McGinnis, S.). Washington DC: Center for Applied Linguistics: 81-89.

Jullian, P. 2000. "Creating word-meaning awareness". English Language Teaching Journal 54: 47-77.

Krashen, S. 1982. Principles and Practices in Second Language Acquisition. Oxford: Pergamon Press.

Komorowska, H. 1988. "Ćwiczenia przedkomunikacyjne: leksyka”. (w) Ćwiczenia komunikacyjne w nauce języka obcego. (red. Komorowska, H.). Warszawa: WSiP: 75-116.

Lipińska, E. 2003. Język ojczysty, język obcy, język drugi. Wstęp do badań dwujęzyczności. Kraków: Wydawnictwo Uniwersytetu Jagiellońskiego.

Lipińska, E. i Seretny, A. 2012a. Między językiem ojczystym a obcym. Nauczanie i uczenie się języka odziedziczonego w chicagowskiej diasporze polonijnej. Kraków: Księgarnia Akademicka.

Lipińska, E. i Seretny, A. 2012b. “Uczący się języka polskiego jako obcego/drugiego w środowisku endolingwalnym - ich umiejętności i potrzeby". Kwartalnik Polonicum 1: 2-10.

O'Malley, J.M. i Chamot, U. 1990. Learning Strategies in Second Language Acquisition. Cambridge: Cambridge University Press.

Nation, I.S.P. 2001. Learning Vocabulary in Another Language. Cambridge: Cambridge University Press.

\footnotetext{
14 Dobór miał charakter celowy, a nie losowy - kwestionariusz wypełniali wszyscy uczący się na poziomie B.
} 
Oxford, R. 1990. Language Learning Strategies: What Every Teacher Should Know. Rowley, Mass.: Newbury House.

Pawlak, M. 2009. “Metodologia badań nad strategiami uczenia się". Neofilolog 32: 65-83.

Polinsky, M. i Kagan, O. 2007. "Heritage languages: In the 'wild' and in the classroom". Language and Linguistics Compass 1: 368-395.

Rubin, J. 1975. "What the 'good language learner' can teach us?". TESOL Quarterly 9: 41-51.

Schmitt, N. 1997. "Vocabulary learning strategies". (w) Vocabulary: Description, Acquisition and Pedagogy. (red. Schmitt, N. i McCarthy, M.). Cambridge: Cambridge University Press: 199-227.

Schmitt, N. 2000. Vocabulary and Language Teaching. Cambridge: Cambridge University Press.

Seretny, A. 2011. Kompetencja leksykalna uczq̨cych się języka polskiego jako obcego w świetle badań ilościowych. Kraków: Wydawnictwo Uniwersytetu Jagiellońskiego.

Seretny, A. 2015. Słownictwo w dydaktyce języka. Świat słów na przykładzie języka polskiego jako obcego. Kraków: Księgarnia Akademicka.

Van Deusen-Scholl, N. 2003. "Toward a definition of heritage language: sociopolitical and pedagogical considerations". Journal of Language, Identity and Education 2: 211-230.

Valdés, G. 2000. "The teaching of heritage languages: an introduction for Slavic-teaching professionals". (w) The Learning and Teaching of Slavic Languages and Cultures. (red. Kagan, O. i Rifkin, B.). Bloomington, Indiana: Slavica: 375-403. 